\title{
PENGARUH HARGA KAMAR DAN FASILITAS HOTEL TERHADAP KEPUASAN KONSUMEN DI SHANGRILA HOTEL SURABAYA
}

\author{
Yunni Rusmawati DJ \\ Prodi Manajemen, Fakultas Ekonomi, Universitas Islam Lamongan \\ Jl. Veteran No.53A Lamongan \\ Telp. ( 0322 ) 324706, Faks. ( 0322 ) 324706 \\ Email :jpim@unisla.ac.id
}

\begin{abstract}
ABSTRAK
Hotel merupakan salah satu alternatif penginapan yang cukup diminati oleh masyarakat pendatang, oleh karena itu harga sangat berpengaruh untuk memikat para konsumen untuk menginap. Dalam dunia pemasaran konsumen adalah faktor utama dalam keberhasilan usaha. Permasalahan dalam penelitian ini adalah apakah harga kamar $\left(X_{1}\right)$ dan fasilitas hotel $\left(X_{2}\right)$ berpengaruh secara parsial maupun simultan terhadap kepuasan konsumen di Shangrila Hotel Surabaya dan variabel manakah yang paling dominan mempengaruhi kepuasan konsumen di Shangrila Hotel Surabaya. Penelitian ini merupakan penelitian kuantitatif, dengan menggunakan analisis data sebagai berikut : Uji Validitas, Uji Realibilitas, Regresi Linier Berganda, Uji t dan Uji $F$. Dari hasil yang diperoleh dengan uji validitas dengan $r_{\text {tabel }}$ sebesar 0,234 dan semua variabel dinyatakan valid karena $>r_{\text {tabel }}$. Uji reliabilitas juga menyatakan reliabel karena > 0,6. Hasil regresi linier berganda $Y=2,988+0,541\left(X_{1}\right)+0,204\left(X_{2}\right)$, menunjukkan bahwa harga kamar lebih dominan dalam mempengaruhi kepuasan konsumen. Penentuan hasil uji koefisien determinasi menunjukkan 43\% kepuasan konsumen dipengaruhi oleh harga kamar dan fasilitas hotel, 57\% sisanya dipengaruhi oleh variabel lain (pelayanan, lokasi dan promosi). Hasil uji $t$ menunjukkan harga kamar $(5,909)$ dan fasilitas hotel $(2,284)>t_{\text {tabel }}(1,955)$ ini menunjukkan $H_{0}$ ditolak dan $H_{a}$ diterima. Hasil uji $F$ menunjukkan $F_{\text {hitung }}(27.421)>F_{\text {tabel }}(3,11)$, ini berarti $H_{0}$ ditolak $H_{a}$ diterima. Dari penelitian dapat disimpulkan bahwa harga kamar dan fasilitas hotel memiliki pengaruh yang signifikan terhadap kepuasan konsumen baik secara parsial maupun secara simultan, dan variabel yang paling dominan adalah harga kamar.
\end{abstract}

Kata kunci : Harga Kamar, Fasilitas Hotel, Kepuasan Konsumen 


\section{PENDAHULUAN}

Seiring kemajuan zaman Kota Surabaya mengalami perkembangan dalam pembangunan dengan pesat seiring dengan perkembangan ilmu pengetahuan dan tekhnologi yang semakin maju. Pembangunan tersebut meliputi berbagai sektor salah satunya adalah sektor pariwisata. Sektor pariwisata dirasakan mempunyai prospek yang cukup cerah untuk masa yang akan datang sebagai penghasil devisa negara maupun daerah. Selain itu, dengan adanya pembangunan di sektor pariwisata akan membantu dalam rangak mengenalkan berbagai ragam kebudayaan yang memiliki ciri khas tersendiri pada masing-masing daerah yang ada di Indonesia kepada wisatawan asing maupun daerah.

Hotel merupakan salah satu alternatif penginapan yang cukup diminati oleh masyarakat pendatang, oleh karena itu harga sangat berpengaruh untuk memikat para konsumen untuk menginap. Dalam dunia pemasaran konsumen adalah faktor utama dalam keberhasilan usaha. Adapun untuk menunjang hal tersebut berbagai upaya dilakukan oleh pemerintah dan pengusaha perhotelan. Salah satu upaya yang di tempuh adalah dengan menyediakan sarana dan prasarana penginapan atau hotel yang baik

Shangrila Hotel Surabaya adalah perusahaan yang bergerak dalam bidang jasa perhotelan, dimana bisnis perhotelan ini mempunyai kecenderungan yang sensitif terhadap fluktuasi perekonomian dan kebijakan pemerintah. Dalam situasi dan kondisi yang demikian, maka dapat menimbulkan pesaingan yang ketat dalam usaha jasa perhotelan tersebut. Hal ini ditunjang pula dengan adanya fasillitasfasilitas yang ada, yaitu kemudahan dalam perkreditan dari perbankan, sehingga mengakibatkan usaha jasa perhotelan tersebut mempunyai kesempatan untuk memperbaiki dan memperkembangkan usahanya, agar memiliki prospek yang semakin cerah di masa-masa yang akan datang.

Berdasarkan latar belakang Apakah ada pengaruh harga kamar dan fasilitas hotel secara parsial terhadap kepuasan konsumen pada Shangrila Hotel Surabaya. Apakah ada pengaruh harga kamar dan fasilitas hotel secara simultan terhadap kepuasan konsumen pada Shangrila Hotel Surabaya. Variabel manakah yang paling dominan antara harga kamar dan fasilitas hotel terhadap kepuasan konsumen pada Shangrila Hotel Surabaya.

Tujuan penelitian ini adalah Untuk mengetahui apakah ada pengaruh harga kamar dan fasilitas hotel secara parsial terhadap kepuasan konsumen di Shangrila Hotel Surabaya. Untuk mengetahui apakah ada pengaruh harga kamar dan fasilitas hotel secara simultan terhadap kepuasan konsumen di Shangrila Hotel Surabaya. Untuk mengetahui variabel manakah yang paling dominan harga kamar dan fasilitas hotel terhadap kepuasan konsumen pada Shangrila Hotel Surabaya.

Menurut Budi (2013;2). Hotel adalah suatu perusahaan yang dikelola oleh pemiliknya dengan menyediakan pelayanan makanan, minuman dan fasilitas kamar untuk tidur kepada orang-orang yang sedang melakukan perjalanan dan mampu membayar dengan jumlah yang wajar sesuai dengan pelayanan yang diterima tanpa adanya perjanjian khusus. Hotel memiliki berbagai jenis harga kamar. Harga kamar tersebut berbeda-beda tergantung pada jenis dan luas kamar. Hal yang membedakan adalah lokasi kamar, arah pemandangan, dan fasilitas yang tersedia. Harga kamar secara garis besar dibagi atas dua macam, yaitu harga pasti dan harga potongan. Harga pasti adalah 
harga kamar yang tidak dapat ditawar atau tidak mendapatkan potongan. Harga kamar ini persis dengan harga yang dikeluarkan oleh pihak manajemen dalam bentuk brosur, sedangkan harga potongan adalah harga kamar standar yang dipotong beberapa persentase tertentu.

Harga merupakan nilai barang atau jasa yang diungkapkan dalam satuan rupiah atau satuan mata uang lainnya. Dalam hal ini harga jual merupakan suatu yang digunakan untuk mendapatkan sejumlah barang dan jasa serta pelayanannya. Harga dapat diungkapkan menjadi berbagai istilah yaitu, iuran, tarif, sewa, bunga, premium, komisi, upah, gaji, honorarium, SPP, dan sebagainya. Berikut ini adalah Pengertian Harga Menurut Para Ahli. (Tjiptono, 2011: 465). Harga adalah sejumlah uang (dalam satuan moneter) dan aspek lain (non-moneter) yang mengandung kegunaan tertentu yang diperlukan untuk mendapatkan suatu produk. Sedangkan dilihat dari sudut pandang pemasaran, harga merupakan satuan moneter atau ukuran lainnya (termasuk barang dan jasa lainnya) yang ditukarkan agar memperoleh hak dan kepemilikan atau penggunaan suatu barang atau jasa. Tujuan penentuan harga perlu ditentukan terlebih dahulu, agar tujuan perusahaan dapat tercapai. Hal ini penting karena tujuan perusahaan merupakan dasar atau pedoman bagi perusahaan dalam menjalankan kegiatan pemasaran, termasuk kebijakan penentuan harga. Sebelum harga itu ditetapkan, manajer harus menetapkan tujuan penentuan harga tersebut.

Menurut Tjiptono (2013 :152-153) tujuan penetapan harga antara lain :

1. Tujuan berorientasi pada laba.

Tujuan ini dikenal dengan istilah Maksimisasi Laba. Dalam era persaingan global yang kondisinya sangat kompleks dan banyak variabelyang berpengaruh terhadap daya saing setiap perusahaan.

2. Tujuan berorientasi pada Volume.

Tujuan ini dikenal dengan istilah Volume Pricing Objectives. Harga ditetapkan sedemikian rupa agar dapat mencapai targetvolume penjualan (dalam ton, $\mathrm{kg}$, unit, dll), nilai penjualan (Rp) atau pangsa pasar (absolute maupun relatif).

\section{Tujuan Berorientasi pada Citra (Image)}

Suatu perushaan dapat dibentuk melalui strategi penetapan harga. Perusahaan dapat menetapkan harga tinggi untuk membentuk atau mempertahankan citra prestisius. Sementara itu harga rendah dapat digunakan untuk membentuk citra nilai tertentu (image of value), misalnya dengan memberikan jaminan bahwa harganya merupakan harga yang terendah di suatu wilayah tertentu.

\section{Tujuan Stabilisasi Harga}

Bila suatu perusahaan menurunkan harganya, maka para pesaingnya harus menurunkan pula harga mereka. Kondisi seperti ini yang mendasari terbentuknya tujuan stabilisaasi harga dalam industri-industri tertentu yanng produknya sangat terstandarisasi misalnya Minyak Bumi.

5. Tujuan-tujuan Lainnya

Harga dapat pula ditetapkan dengan tujuan mencegah masuknya pesaing mempertahankan loyalitas pelanggan, mendukung penjualan ulang, atau menghindari campur tangan pemerintah. Organisasi non-profit juga dapat menetapkan tujuan penetapan harga yang berbeda, misalnya unntuk 
mencapai partial cost recovery, full cost recovery, atau menetapkan social price.

Menurut Gitosudarmo (2005 :223-227) terdapat tiga hal dalam menentukan harga jual pada suatu perusahaan hotel yaitu: Pertama Dasar biaya yang dipertimbangkan dalam suatu Tarif Sewa Kamar akan menjadi pertimbangan utama bagi perusahaan dalam menentukan harga. Pada umumnya perusahaan menetapkan harga menggunakan dasar biaya yang digunakan dan kemudian ditambah dengan keuntungan yang diinginkan oleh perusahaan. Kedua Dasar konsumen mungkin saja tidak sesuai dengan apa yang dikehendaki oleh konsumen. Maka diperlukan penentuan harga berdasarkan selera konsumen atau permintaan konsumen. Dasar penentuan harga yang seperti ini, maka konsumen akan merasa puas terhadap harga yang ditetapkan oleh perusahaan. Konsumen menganggap harga tersebut telah sesuai dengan kualitas jasa yang didapatkannya. Ketiga Dasar persaingan dengan perusahaan lain yang sejenis dan merupakan pesaingpesaingnya. Cara yang dapat dilakukan oleh perusahaan dalam melawan pesaingnya adalah dengan menerapkan potongan harga atau diskon, penjualan secara kredit atau angsuran.

Hasil riset Shankar, Smith \& Rangaswamy (2003) dalam buku (Tjiptono, Ph.D \& Greogius Candra. 2011: 290) terhadap kepuasan dan loyalitas konsumen hotel pada konteks lingkungan online dan offline menunjukkan bahwa tingkat kepuasan konsumen pada jasa yang dipilih secara online sama dengan jasa yang dipilih secara offline, namun loyalitas pada penyedia jasa lebih tinggi pada jasa yang dipilih secara online dibandingkan yang offline. Mereka juga menemukan bahwa loyalitas dan kepuasan memiiki hubungan timbal balik yang saling memperkuat secara pasif satu sama lain.

\section{METODE PENELITIAN}

Untuk mencapai tujuan sesuai dengan yang diharapkan dalam penyusunan skripsi iniguna memperoleh kesimpulan, maka data yang terkumpul akan dianalisa dengan menggunakan data dalam bentuk angkaangka. Dalam penelitian ini penulis menggunakan analisis kuantitatif yang mana menurut Sugiyono (2010:23) adalah data-data yang berbentuk angka, atau data kualitatif yang diangkakan.

Populasi adalah Keseluruhan obyek penelitian (Arikunto,2010:173). Populasi adalah wilayah generalisasi yang terdiri atas obyek atau subyek yang mempunyai kualitas dan karakteristik tertentu yang ditetapkan oleh peneliti untuk dipelajari dan kemudian ditarik kesimpulannya. (Prof DR. Sugiyono, 2012:80). Dan penggunaan populasi dalam penelitian ini adalah pengguna jasa kamar hotel dengan jumlah populasi 250 orang per bulan Oktober- Desember 2018.

Teknik pengambilan sampel dalam penelitian ini dilakukan dengan teknik Strategi Simple Random Sampling (sampel sederhana) yaitu pengambilan sampel dari populasi dilakukan secara acak tanpa memperhatikan strata yang ada dalam populasi itu (Sugiyono, 2012;120).

Dalam penelitian ini mengukur variabel digunakan skala Likert, Menurut Sugiyono (2015;93) Skala Likert digunakan untuk mengukur sikap, pendapat dan persepsi seseorang atau sekelompok orang tentang fenomena sosial. Dalam penelitian fenomena sosial ini telah ditetapkan secara spesifik oleh peneliti, yang selanjutnya disebut sebagai variabel penelitian. Responden diminta untuk mengisi pertanyaan skala ordinal berbentuk verbal dengan jumlah kategori tertentu bisa 5 sampai 8. Skor jawaban dari responden berkisar pada nilai 1 sampai 5 
yang mana untuk pengelompokan jawaban dari perhitungan masing-masing nilai diberi skor.

Dalam penelitian ini yang menjadi variabel bebas $(\mathrm{X})$ adalah :

a. Variabel X1, yaitu harga kamar

Harga merupakan jumlah uang (satuan moneter) atau aspek lain (non-moneter) yang mengandung utilitas/kegunaan tertentu yang diperlukan untuk mendapatkan sebuah produk (barang, jasa, orang, tempat, ide, informasi dan organisasi) (Tjiptono, 2013;315)

Indikator harga adalah :

1. Kecepatan dan ketepatan resepsionis dalam memberikan pelayanan harga kepada para tamu.

2. Harga yang sesuai dengan fasilitas yang ada.

3. Harga yang sesuai dengan kualitas jasa yang diberikan.

b. Variabel X2, yaitu Fasilitas hotel

dalam penelitian ini yang dimaksud fasilitas adalah fasilitas yang dimiliki atau disediakan untuk konsumen Grand Mahkota Hotel Lamongan.

Indikator dari fasilitas adalah :

1. Kondisi hotel dan kebersihan ruangan.

2. Kamar yang nyaman, bersih dan rapi untuk di pakai.

3. Ketersediaan lahan parkir hotel yang memadai.

c. Dalam penelitian ini yang menjadi variabel terikat adalah

Kepuasan Konsumen (Y) Kepuasan Konsumen adalah tingkat perasaan sseseorang setelah membandingkan kinerja (hasil) yang ia rasakan dibandingkan dengan harapannya (Kotler et al dalam Tjiptono, 2008;24)

Indikator :

1. Pelayanan yang sudah sesuai dengan harapan konsumen

2. Kesediaan pelanggan untuk merekomendasikan kepada orang lain.

3. Puas dan ingin menggunakan jasa hotel di kemudian hari.

Untuk membatasi masalah yang dihadapi, peneliti mengadakan teknik analisa sebagai berikut : Uji Validitas, Uji Reliabilitas, Analisis Regresi Linier Berganda, Korelasi Berganda, Uji t, dan Uji F.

\section{PEMBAHASAN}

Metode pengambilan sampel dilakukan dengan menggunakan strategi random sampling (sampling sederhana). Pengelompokan responden berdasarkan jenis kelamin dan pekerjaan.

Responden yang menggunakan jasa kamar hotel di Shangrila Hotel Surabayal kebanyakan pria yaitu sebanyak 53,5\% yang mempunyai kecenderungan mendominasi untuk menginap dibandingkan dengan responden wanita sebanyak 46,5\%. Hasil ini menunjukkan bahwa harga kamar dan fasilitas hotel memiliki peranan dalam mengambil keputusan untuk menginap di Shangrila Hotel Surabaya.

Responden yang menggunakan jasa kamar hotel dengan tingkat usia mayoritas berusia 26-35 tahun 35,21\%. Pada usia antara 26-35 tahun merupakan kelompok usia responden yang sering memilih menginap di Shangrila Hotel Surabaya.

Hasil penelitian ini diperoleh dari hasil penyebaran kuesioner dengan jumlah 
responden sebanyak 71 responden. Kuesioner ini terdiri dari 2 variabel bebas yaitu harga kamar (X1) dan fasilitas hotel (X2) sedangkan variabel terikat adalah kepuasan konsumen (Y) di Shangrila Hotel Surabaya

Dari perhitungan analisis data disimpulkan beberapa hal sebagai berikut :

Dari hasil regresi berganda didapatkan hasil sebagai berikut :

1. Hasil analisa perhitungan regresi linier berganda, dapat ditentukan persamaan model regresinya sebagai berikut : $\mathrm{Y}=2,988+0,541 \mathrm{X}_{1}+0,204 \mathrm{X}_{2}$

$\mathrm{a}=2,988$ merupakan konstanta yang berarti bahwa variabel bebas dalam penelitian (Harga Kamar dan Fasilitas Hotel) pengaruhnya $=0$, maka hasil dari Kepuasan Konsumen adalah 2,988.

$\mathrm{b}_{1}=0,541$ Artinya jika harga kamar mengalami kenaikan $1 \%$ maka Kepuasan konsumen akan mengalami peningkatan sebesar 0,541, dengan asumsi variabel pelayanan, lokasi dan promosi yang mempengaruhi dianggap konstan (a dan $X_{2}=0$ ).

$\mathrm{b}_{2}=0,204$ Artinya jika fasilitas hotel mengalami kenaikan $1 \%$ maka Kepuasan konsumen akan mengalami peningkatan sebesar 0,204, dengan asumsi variabel pelayanan, lokasi dan promosi yang mempengaruhi dianggap konstan (a $\operatorname{dan} \mathrm{X}_{1}=0$ ).

Dengan demikian dapat disimpulkan dapat ditarik kesimpulan bahwa harga kamar (X1) meerupakan faktor yang paling dominan berpengaruh terhadap kepuasan konsumen (Y) di Shangrila Hotel Surabaya.
2. Nilai $t_{\text {hitung }}$ dari perhitungan model regresi pada variabel harga kamar (X1). Dari hasil uji t diperoleh nilai $\mathrm{t}$ hitung 5,909 dengan taraf nilai signifikan $\alpha=0,05$ maka $\mathrm{t}_{\alpha / 2}=\mathrm{t}_{0,025}$; $\mathrm{df}=\mathrm{n}-\mathrm{p}=71-2=69$ maka diperoleh $\mathrm{t}_{\text {tabel }}=1,955$, sehingga $\mathrm{t}_{\text {hitung }}$ $5,909>\mathrm{t}_{\text {tabel }} 1,955$, maka $\mathrm{H}_{0}$ ditolak dan $\mathrm{H}_{\mathrm{i}}$ diterima, yang artinya bahwa ada pengaruh yang signifikan secara parsial antara variabel harga kamar $\left(\mathrm{X}_{1}\right)$ terhadap Kepuasan konsumen $(\mathrm{Y})$ di Shangrila Hotel Surabaya.

Nilai $t_{\text {hitung }}$ dari perhitungan model regresi pada variabel fasilitas hotel (X2). hasil uji t diperoleh nilai t hitung 2,284 dengan taraf nilai signifikan $\alpha=$ 0,05 maka $\mathrm{t}_{\alpha / 2}=\mathrm{t}_{0,025} ; \mathrm{df}=\mathrm{n}-\mathrm{p}=71$ $-2=69$ maka diperoleh $\mathrm{t}$ tabel $=$ 1,955 , sehingga $t_{\text {hitung }} 2,284>t_{\text {tabel }}$ 1,955, maka $\mathrm{H}_{0}$ ditolak dan $\mathrm{H}_{\mathrm{i}}$ diterima, yang artinya bahwa ada pengaruh yang signifikan secara parsial antara variabel fasilitas hotel $\left(\mathrm{X}_{2}\right)$ terhadap Kepuasan konsumen (Y) di Shangrila Hotel Surabaya.

Berdasarkan uraian diatas hasil $t_{\text {hitung }}$ dan $t_{\text {tabel }}$ menunjukkan bahwa antara variabel harga kamar (X1) dan fasilitas hotel (X2) secara parsial harga kamar lebih besar berpengaruh besar terhadap kepuasan konsumen (Y).

3. Dari hasil uji $\mathrm{F}$ diperoleh $\mathrm{F}$ hitung $=$ 27,421 dan $\mathrm{F}_{\text {tabel }}=3,11$ dengan tingkat signifikan $0,000<0,05$, artinya harga kamar dan fasilitas hotel secara simultan mempengaruhi kepuasan konsumen, karena $\mathrm{F}_{\text {hitung }}>\mathrm{F}_{\text {tabel }}$.

Jadi perhitungan secara simultan dari variabel harga kamar (X1) dan fasilitas hotel (X2) di Shangrila Hotel Surabaya berpengaruh terhadap kepuasan konsumen (Y) secara simultan yang berarti $\mathrm{H}_{0}$ ditolak dan $\mathrm{H}_{1}$ diterima. 


\section{KESIMPULAN}

Berdasarkan hasil perhitungan, analisis, dan pengujian dari penelitian ini, maka jawaban dari rumusan masalah dapat disimpulkan sebagai berikut :

1. Hasil Persamaan Regrasi Linier Berganda diperoleh persamaan $\mathrm{Y}=2,988+0,541\left(\mathrm{X}_{1}\right)+0,204\left(\mathrm{X}_{2}\right)$ Ini menunjukkan bahwa variabel kepuasan konsumen adalah 2,988 jika variabel harga kamar dan fasilitas hotel pengaruhnya $=0$. Saat harga kamar mengalami kenaikan $1 \%$ maka kepuasan konsumen naik 0,541, dan jika fasilitas hotel mengalami kenaikan $1 \%$ maka kepuasan konsumen naik 0,204 .

2. Secara parsial terdapat pengaruh positif hal ini di buktikan dari hasil uji $t$ (parsial) diperoleh $t_{\text {hitung }}$ variabel harga kamar $\left(\mathrm{X}_{1}\right)$ sebesar 5,909 dan variabel Fasilitas Hotel $\left(\mathrm{X}_{2}\right)$ diperoleh $\mathrm{t}_{\text {hitung }}$ 2,284 dengan nilai signifikan kurang dari 0,05 yang secara berurutan masing-masing sebesar 0,000 dan 0,025 . Hal ini berarti variabel harga kamar dan fasilitas hotel secara parsial mempunyai pengaruh yang signifikan dalam mendorong kepuasan konsumen di Shangrila Hotel Surabaya

3. Secara simultan variabel harga kamar dan fasilitas hotel mempunyai pengaruh yang signifikan terhadap kepuasan konsumen pada Shangrila Hotel Surabaya. Hal ini bisa dibuktikan dengan uji F. Diperoleh $F_{\text {hitung }}$ sebesar 27,421 dan $F_{\text {tabel }}=3,11$ dengan tingkat signifikan 0,000 . Artinya secara simultan harga kamar dan fasilitas hotel berpengaruh terhadap kepuasan konsumen di Shangrila hotel Surabaya, tingkat signifikan $<0,05$ dan $F_{\text {hitung }}>F_{\text {tabel. }}$

4. Dari hasil Analisis regresi berganda dilihat pada Standardized Coefficients Beta yang berpengaruh paling dominan Jurnal Penelitian IImu Manajemen adalah Variabel Harga Kamar $\left(\mathrm{X}_{1}\right)$ dengan nilai sebesar 0,564 .

\section{SARAN}

Berdasarkan analisis dan keseluruhan pembahasan, maka beberapa saran yang dapat diberikan pada Shangrila Hotel Surabaya adalah :

1. Lebih meningkatkan kepuasan konsumen dengan cara memberikan Harga Kamar dan Fasilitas Hotel yang memadai sehingga konsumen merasa nyaman untuk menggunakan jasa penginapan di Shangrila Hotel Surabaya.

2. Diharapkan hasil dari penelitian ini, dapat dijadikan pertimbangan dalam meningkatkan Kepuasan konsumen yang selama ini telah dijalankan dengan baik oleh Shangrila Hotel Surabaya.

\section{DAFTAR PUSTAKA}

Arikunto, S. 2010. Prosedur Penelitian Suatu Pendekatan Praktik. Jakarta. Rineka Cipta

Budi, A.P. 2013. Manajemen Marketing Perhotelan. Yogyakarta. CV Andi Offset

Gitosudarmo, Indriyo. 2005. Manajemen Pemasaran. Edisi Pertama. Yogyakarta, BPFE

Tjiptono, Fandy dan Gregorius Candra. 2011. Service Quality dan Satisfaction. Yogyakarta. CV Andi Offset

Tjiptono, Fandy. 2008. Strategi Pemasaran. Yogyakarta. Penerbit Andi 
Sugiyono. 2012. Metode Penelitian Kuantitatif Kualitatif dan $R \& D$. Bandung. Penerbit Alfabeta

Sugiyono. 2015. Statistika Untuk Penelitian. Bandung. Penerbit Alfabeta

Sugiyono. 2014. Metode Penelitian Kuantitatif Kualitatif dan $R \& D$. cetakan ke-20. Bandung: Alfabeta.

Sunyoto, Danang. 2013. Teori, Kuesioner \& Analisis Data Untuk Pemasaraan dan Perilaku Konsumen. cetakan pertama. Yogyakarta: Graha Ilmu

Sunyoto, Danang. 2015. Pemasaran Konsumen dan Pemasaran. Jakarta. Penerbit Caps 